\title{
THE USE OF HUMOR IN PSYCHOTHERAPY
}

\author{
A.H. CHAPMAN*, MIRIAN CHAPMAN-SANTANA
}

SUMMARY - Humor can be a useful treatment technique in the hands of some psychotherapists. It may help the patient to see painful life events and situations from less threatening perspectives, and can take the anxiety and guilt out of many difficult circunstances and incidents. Humor can be valuable in talking with parents about the problems of their adolescent children, in working with adolescents themselves, in discussing difficulties encountered in the workplace and in social environments, in decreasing obstructive awe of the therapist and apprehensiveness about treatment, in dealing with problems such as male sexual impotence, and in many other areas. Some therapists, however, handle humor awkwardly; in their hands it misfires or falls flat, and they should avoid it.

KEY WORDS: psychotherapy, humor.

\section{Uso do humor em psicoterapia}

RESUMO - O humor pode ser uma técnica terapêutica útil nas mãos de alguns psicoterapeutas. O humor pode ajudar um doente a ver episódios e situaçð̃es dolorosas da sua vida sob perspectivas menos ameaçadoras e pode retirar sentimentos de ansiedade e culpa provenientes de muitos acontecimentos e situaçðes. $O$ humor pode ser valioso quando o terapeuta está conversando com măes e pais sobre os problemas dos seus filhos adolescentes, em diálogos com adolescentes, na análise das dificuldades no trabalho e em outros ambientes sociais, para desfazer temores em relação ao terapeuta, para reduzir a ansiedade relativa ao tratamento em si mesmo, no tratamento de impotência sexual em homens e em muitos outros problemas e tipos de doentes. Todavia, alguns terapeutas năo usam bem o humor e nas mãos deles acaba dando errado ou deixa de produzir os efeitos desejados; estes terapeutas năo devem utilizar-se do humor.

PALAVRAS-CHAVE: psicoterapia, humor.

Writers on psychotherapy rarely comment on the use of humor in $\mathrm{it}^{12}$. In our search of the literature we could find only two therapists who feel it can be employed as a therapeutic instrument ${ }^{11,12}$. All other therapists describe therapeutic communication as a serious procedure in which humor would be either a frivolous irrelevance or a mistake implying that the therapist was taking the patient's problems lightly or did not consider them, and perhaps the patient himself, worthy of his time and earnest consideration.

The two writers who feel that humor has its place in treatment are Jack J. Leedy and Harry Stack Sullivan. Leedy in his book Poetry Therapy ${ }^{11}$ states that humor is useful both in patienttherapist sessions and in hospital or ward mimeographed or photocopied publications, such as newssheets or newspapers put out by patients and staff for distribution to the whole patient population. However Leedy gives no specific examples of humorous poetry or prose in such a publication in the hospital he works in, nor does he give instances of it in psychiatric interviews.

*From the Samur Hospital, Vitória da Conquista, Bahia, Brazil. Aceite: 22-agosto-1994. 
Harry Stack Sullivan in his book The Psychiatric Interview ${ }^{12}$ fells that humor has an occasional role in psychotherapy, and in other places ${ }^{10}$ gives examples of his utilization of it. Former patients of Sullivan, who was one of America's foremost psychiatrists in the 1930s and 1940s, recall his use of humor, often with the dramatic flair for which he was well known. For example, if a guilt-ridden patient told of his first act of masturbation, or of some other sexual pecadillo, Sullivan might stare impressively at him or her and say, "And at that point, as I get it, the world came to an end!" If an anxious patient told Sullivan about a violent argument he had with one of his parents shortly before that parent became suddenly ill with a heart attack Sullivan might say, "Well, that's the eight time today that a patient has told me that he rebelled against his father", and Sullivan was not above counting on his fingers just before he said it. If a patient recounted an event in his life which he felt was heinous or morally foul Sullivan might ejaculate, "Do you expect me to collapse in horror about a think like that?" or "My God! How simply awful", and proceed to fall ludicrously back in his chair in mock prostration.

What is humor? Our search through the literature indicated that only two well known psychiatric writers consider humor and give opinions about what causes something to be humorous. Sigmund Freud, in his book Wit and Its Relation to the Unconscious ${ }^{6}$ writes, "The technique of wit is found in the use of a unique form of condensation, economy of expression and brevity quite peculiar to this phenomen... The pleasure in the wit-tendency results from the fact that a tendency, whose gratification would otherwise remain unfulfilled, is actually gratified... The forms of tendency gratified by the wit-technique may be sexual, hostile, agressive, invective and rebellious against authority". In later years Freud ${ }^{7}$, and Kris ${ }^{9}$ after him, elaborate on these ideas but do not basically alter them. However, there is no evidence, either in his writings or in the accounts by people who were treated by him, that Freud used humor in his therapy.

Sullivan defines humor in a broader way, consonant with his interpersonal concepts of psychiatry and psychology, and we are inclined to follow him. He defines humor as incisive comments which throw broad relief "the (patient's) capacity for maintaining a sense of proportion in the tapestry of life... and (one's) importance in the life situation in which one finds oneself". In each of the three examples of Sullivan's humor given above Sullivan utilizes exaggerated, dramatic remarks to indicate that what the patient regards as bad or guilt-ridden is really of little importance and that the problem lies not in the act itself but in the patient's anxious or guilty feelings about it.

\section{VARIOUS USES OF HUMOR IN PSYCHOTHERAPY}

In talking with parents about the difficulties of their adolescent children. When interviewing parents who are discouraged or depressed about the problems of their adolescent children, both inside and outside the home, a therapist may sometimes throw these difficulties into their broader perspective by citing the old psychiatric adage: "Adolescence is not a stage of life; it is a psychiatric diagnosis". In saying this the psychotherapist stresses the commonness of such troubles and, on the whole, their good prognosis. At other times the therapist may appropriately quote Mark Twain: "When I was eighteen I thought my father was the most ignorant man in the world; when I was nineteen I was astonished at how much he had learned in only one year". Another quotation from Mark Twain which is relevant to many parent-child conflicts is: "Adam was but human - this explains it all. He did not want the apple for the apple's sake, he wanted it only because it was forbidden".

In talking with adolescents about their parents and other adults. The therapist can sometimes raise a laugh or a grin by reflecting a teen-ager's resentment against restrictive parents or other adult authorities by referring to them as "super-Daddy", "super-Mom" or "super-boss". At other times he may be able to help a teenager to stand back and view more realistically the turmoil which minor things can precipitate in some homes and in situations outside them by comparing it to the farcical turbulance that characterizes some humorous television programs: "This house sounds as if half the time a session from A Escolinha do Professor Raimundo or Os Trapalhðes is going on in it". Some adolescent-adult confrontations are funny when you can take a few steps back and look at them more objectively. Rows over boy's extreme hair styles and earrings and girls' skimpy blouses and glued-on blue jeans fall in this category. 
In discussing general social and economic situations. In some cases one of the patient's central problems consists of his or her marked feelings of inferiority and inadequacy in the workplace, in social gatherings and in other public situations. The therapist at times can put the otherwise awesome people in the patient's life into another perspective, and in doing so cut them down to realistic size, by posing the question: "How would all these people look at those times if they had no clothes on? Just think of all those potbellies, drooping breasts, sagging bottoms and spindly legs. The mind boggles!". On occasion the therapist may cite the remark which one such patient made after being bawled out in front of others by a domineering supervisor: "Excuse me, Mr. Christs, but I didn't recognize you without your beard". Your patient probably will never actually say such words to anyone (it might indeed be imprudent to do so) but in future encounters with belittling persons these words may pass through his mind and cause these incidents to pass with a slight smile rather than a crestfallen withdrawal. At other times a brutal boss or teacher can be stripped of his terror for the patient by giving him a nickname, at least behind his back: "Well, Miss Azevedo, what has King Kong been up to lately?' We recall one home in which a tyranical father was stripped of his awesomeness by referring to him in family discussings as "Hitler".

In dealing with male sexual impotence. Psychologically caused sexual impotence in men is a common complaint encountered in psychotherapeutic practice. In 1912 Sigmund Freud wrote that, after anxiety states, male sexual impotence was the most common complaint for which patients consulted him ${ }^{\mathbf{3}}$. Many such patients are alarmed and feel themselves to be complete failures because of such a symptom, whereas sexual impotence in a man who until recently performed well has an excellent prognosis if the patient can calmly see his difficulty in a broad medical and interpersonal light. The therapist's main task, as a rule, is to help him do just that. As an opener the therapist may say, "So you feel you're a total failure in life because, for the time being, you can't do what every mongrel dog and stray cat in the streets can do? Come now!" As the patient counters by indicating that this is his only difficulty and that he is successful in other areas, the way is opened for the therapist to intervene, explain, reassure and set the patient at ease; this is the most important step in clearing up this difficulty.

The utilization of black humor. The technical name for black humor is galgenhumor, a German word that literally means gallows' humor. On infrequent occasions a therapist can throw an event into a different light, and reduce it to its proper size, by black humor. For example, if a patient describes how he or she reacted with panic to a bleeding scraped leg in a bicycle accident or a sliced finger in a kitchen mishap, the therapist may wryly say, "All that blood, and you without your spoon". The therapist who employs black humor must know his patient well and be confident of his own ability if black humor is not to misfire, at times badly.

Other uses of humor. When a patient is inhibited by exaggerated respect for a therapist, or even a certain dread of him or her, the therapist at times may assuage such feelings by referring to himself or herself as "a head shrinker", or "a shrink", or "a member of the head shrinker's union". Once in a while a patient mistrusts his therapist's reassurances; he feels that the therapist is trying to give him self-confidence by hidding the awful truth about his personality problems, his symptoms or his life situation. At such a juncture the therapist may cock his head slightly to one side and say, "I only lie to patients on Tuesdays, and today is Friday". In working with patients with acute anxiety attacks, or panic reactions, we sometimes refer to them as episodes of "scared shitlessness" and describe the patient as being "scared shitless" when he is having one of them. Most patients laugh, or at least smile, when they hear their symptoms described (quite accurately, though perhaps vulgarly) in this way, and when a patient can laugh at his problem its terror begins to melt away. When a patient is unduly upset over a minor moral pecadillo the therapist may find it useful to recount Mark Twain's story about his first lie. It occurred, he said, when he was four days old; he screamed loudly to convince his mother that a diaper pin was sticking him when in reality all he wanted was more attention.

There are many other therapeutic situations in which humor can be useful.

\section{WHO SHOULD USE HUMOR, AND WHO SHOULD NOT, IN PSYCHOTHERAPY?}

Some therapists employ humor effectively and some do not. In the hands of the latter it misfires or falls flat, and may be counterproductive or a waste of therapeutic time. The patient, in the presence of such a therapist, may feel that his doctor is taking his problems lightly or is a frivolous person whose seriousness and capacities cannot be trusted.

The difference between a therapist who can utilize humor as a valuable tool and a therapist who cannot probably lies in the nonverbal accompaniments of it. Whether it is effective or not 
usually is due to the voice tones, facial expressions, slight gestures, small changes of body tone and posture and other such nonverbal acts that accompany the humorous comment or interpretation. In our opinion these things cannot be taught. A therapist does them intuitively, without consciously thinking about them. A humorous comment cannot be planned; it must come spontaneously and naturally. Timing is important; the humorous interpretation that strikes home at one point in an interview may go badly astray a minute or two later. Pauses also are important; the slight pause, often toward the end of a sentence before the therapist gives the "punch" word or phrase, is often critical. Above all the therapist must be comfortable with humor; it must come in offhand ways; it cannot be forced. All these things are products of the therapist's personality and his outlook on life and the interpersonal events in it. The therapist who can employ humor well will find it a valuable tool in his psychotherapeutic repertory. The therapist who cannot use it well had best leave it alone.

\section{REFERENCES}

1. Basch MF. Practicing psychotherapy: a casebook. New York: Basic Books, 1992, p 27-34.

2. Budman SH, Hoyt MF, Friedman S. The first session in brief psychotherapy. New York: Guilford Press, 1992, p 93-98.

3. Chapman AH. The treatment techniques of Harry Stack Sullivan. New York: Brunner/Mazel, 1978, p 150-151.

4. Chapman AH, Chapman-Santana, M. Harry Stack Sullivan's concepts of personality development and psychiatric illness. New York: Brunner/Mazel, 1980, pp 90-93, 97-99.

5. Chapman AH. It's all arranged. New York: G.P. Putnam's Sons, 1975, pp 25-26, 149-150.

6. Freud S. Wit and it's relation to the unconscious. New York: Modem Library, 1950, p 16-17.

7. Freud S. Humor. Collected Papers, Vol 5. London: Hogarth Press, 1950: 215-221.

8. Freud S. The most prevalent form of degradation in erotic life. Collected Papers, Vol 4. London: Hogarth Press, 1925, p 203-216.

9. Kris E. Laughter as a creative process. Int J Psychoanal 1940, 21: 82-89.

10. Kvarnes RG, Parloff GH. A Harry Stack Sullivan case seminar. New York: W.W. Norton, 1976, pp 40-41, 82, 88-89.

11. Leedy JJ. Poetry therapy. Philadelphia: J.B. Lippincott, 1969, p 193, 198, 227.

12. Sullivan HS. The psychiatric interview. New York: W.W. Norton, 1954, p 181-182. 